日本臨床麻酔学会第 26 回大会パネルディスカッション

女性麻酔科医だからできること

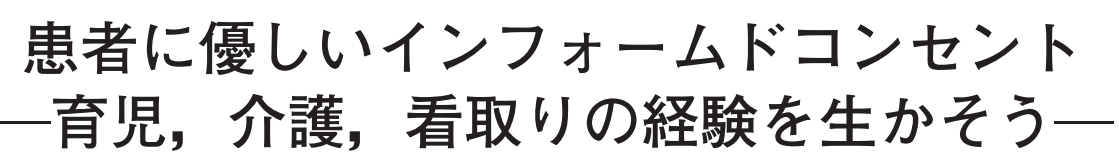

中村久美*

[要旨] 男女差は生物学的要因だけでなく社会的要因にもよっている．女性医師は男 性医師よりも多くの時間を, 育児, 老親の介護, その他の家族的な問題にあてている. しかし, これを否定的にばかりとらえるべきではない，このような経験は，手術や麻 酔に直面している患者やその家族の精神的側面を理解する力を養い, インフォームド コンセントに大いに役立つ. 男性医師も, 同様の力を獲得するためにも, 自分の家族 のためにもっと時間を割くべきである. 性差別の解消は, 女性に男性同様の権利を与 えること(いうなれば, 女性の男性化)だけではなく，男性にも家族のためや趣味を含 めた社会的活動のための時間を与えることによってなされるべきである.

キーワード：インフォームドコンセント, 女性, 麻酔科医

（日臨麻会誌 Vol.28 No.2, 252～258, 2008)

\section{はじめに}

日本臨床麻酔学会の大会や日本麻酔科学会の学術 集会のたびに，女性医師問題のシンポジウムないし はパネルディスカッションがもたれるようになって 久しい。その背景には, 女性医師の働く環境を整備 してほしいという女性医師の側からの要求と, 女性 医師という貴重な人的資源を麻酔科医不足解消の切 り札にしようという，主に管理的立場にある麻酔科 医の思惑があったというべきであろう.

そのようななかで, 日本臨床麻酔学会第 26 回大 会では，まったく新しい切り口での女性医師につい てのパネルディスカッションが提案された。女性麻
酔科医が男性麻酔科医よりも有利な点を議論しよう というのである。

\section{40\%が反対した企画}

複数のメーリングリストを利用して，主に麻酔科 医を対象としたアンケートへの協力を依頼，82通の 回答を得た ${ }^{1)}$ 。そのなかで，「『女性麻酔科医だから できること』というパネルディスカッションのタイ トルについてどう思われますか?」という設問をし 自由に記入してもらったところ，女性回答者 39 名 中 15 名 (38.5\%)が，「意味がない」または「反対」の 趣旨の回答をし，支持する趣旨の回答は 9 名 $(23.1 \%)$ にすぎなかった。一方，男性の回答者は，41名中 17
著者連絡先 中村久美

干 604-8845 京都市中京区壬生東高田町 1-2 京都市立病院麻酔科 


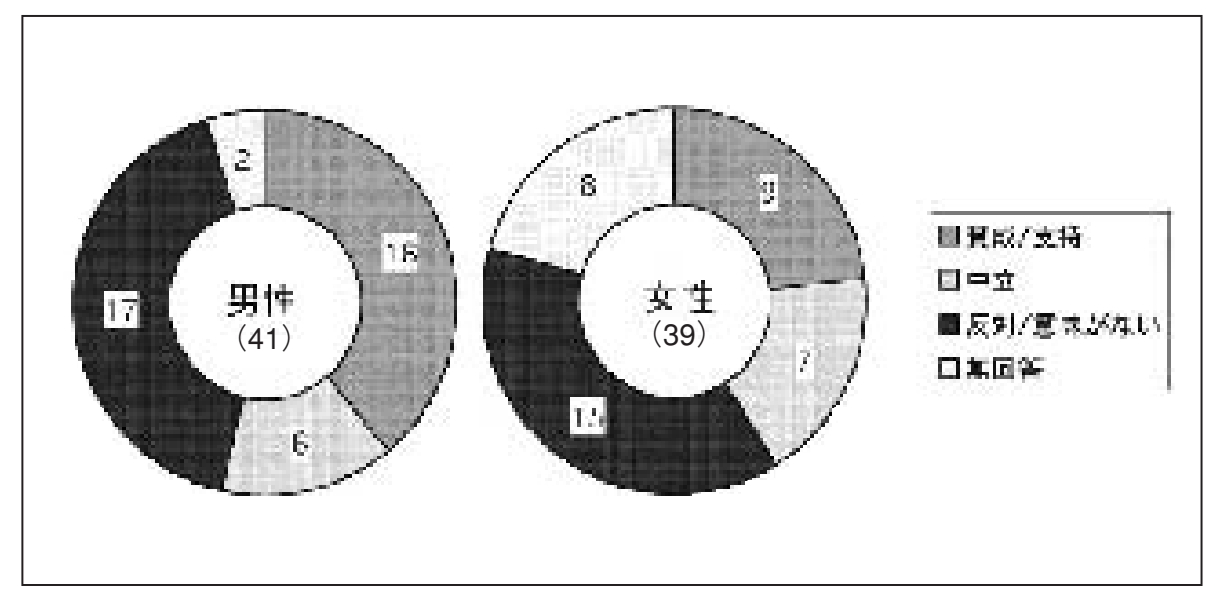

図1 このパネルディスカッションのタイトルを聞いてどう思ったか?

学会前にインターネットを使って施行したアンケートの結果. 自由記入の方式だっ た実際の回答を，「支持する」「どちらでもない」「反対だ/意味がないと思う」の3 段階に分類して男女別に集計した。

名 (41.5\%)が反対， 16 名 (39\%)が肯定的であった (図 1).

このアンケートは，郵送や個人メールによる回答 依頼ではなかったので, 回収率というべき数字は不 明である。推測としては，メールを受け取った総数 に対する回答者の率は低く，男女とも，このパネル ディスカッションの企画に反対の人に回答率が高か ったと考えることもできる。しかし，これだけの医 師，特に女性医師が，今回のパネルディスカッショ ンに反対の意思表明をしたということは，私たちパ ネリストにとつて衝撃であった。早速善後策を話し 合ったが，私たちは結局このパネルディスカッショ ンを敢行することとした。その根拠について説明し たい.

\section{II＼cjkstart絶対的な男女差はY染色体の有無だけ}

男女差のうち絶対的なものは，XYとXXという 染色体の相違だけである。生殖における男女の役割 分担，あるいは性愛の傾向は，相対的な差にすぎな い. 妊娠授乳は男性にはできないが女性でもできな いことがあるし, 男性側の生殖における能力にも個 人差がある。性愛において, 染色体上の性別とは違

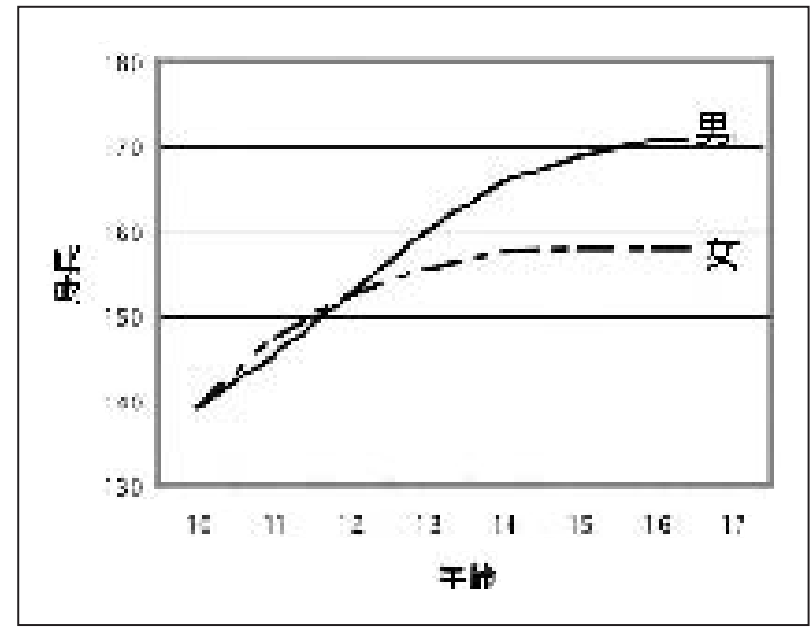

図 2 学齢期の男女の身長の平均值

$10 \sim 17$ 歳の男女別平均身長 $(\mathrm{cm})$.

(平成18年度学校保健統計調査〈京都府〉による)

う傾向を示す男女がいることも，今日では夕ブーで はなくなった。

相対的な男女差として，体型，体力の差がある。 図2は，10歳から 17 歳までの男女の身長の平均值で ある (平成 18 年度学校保健統計調査, 京都府)。平均 值で比較すると，13歳以上では，男性の身長は女性 より大きい.しかし，図3に例示したような個々の 


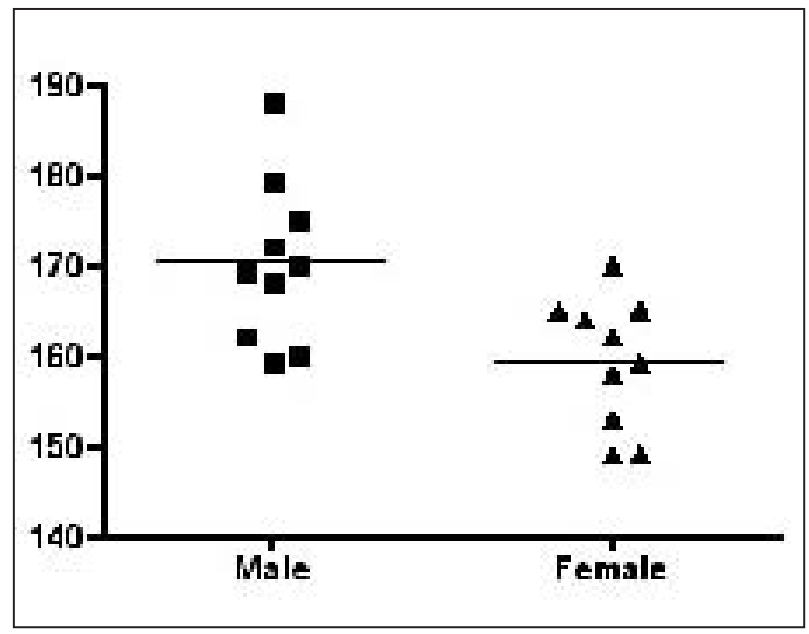

図3 男女差(概念図)

平均值には男女差があっても, すべての個体で男性 が女性より大きい(高い) または小さい(低い)わけで はない.

值を見ると，すべての男性がすべての女性より身長 が高いわけではない.

学力や特技においても, 原因が生物学的特性か社 会的な要因による後天的な差かはともかくとして, 男女差がある程度はある。数学や物理は男性が女性 より強く, 国語や外国語は女性が強い, 男性は器械 いじりが好きな場合が多く, 女性は手芸が器械いじ りより好きな場合が多い, というような平均值の差 である.この点についても, 身長と同様, 数学が語 学より得意な女性も, 器械いじりが手芸より好きな 女性もいくらもいるのであるが，過半数ではないで あろう。

以上のことについて, 細かい点には異論があつた としても, 男女差が存在するという大筋に反対の人 はいないのではないだろうか。では，それにもかか わらず，なぜ女性医師が男女差を議論することに反 対するのか. それは，彼女らが，その議論に負のイ メージしか持てない(損をすることはあっても得を することはないと考える)からであろう。

なぜなら, 大半の女性医師は, 少なくとも学業成 績と職業に対する態度において，女性の平均值から 離れた異端の存在である。彼女たちはたいていの場
合「女なのだから」という言葉により，自分の生 き方を周囲から批判された経験をもっている。その ような批判に抵抗して「男勝り」の生き方を選んで きた女性たちは，男女の特性の差を議論するという 企画に警戒心をもつ。

\section{III それでも企画を敢行する}

第 2 の理由は，医師として女性が少数派であり， 多数派の男性については「だから男は」と言われる ことはあまりないのに，少数派の女性の方は，「だ から女は」とひとからげに批判されやすいからであ ろう。特に，自分の周囲に自分が肯定できない女性 医師がいるとき，「彼女と一緒にされたくない」と いう気持ちが強くなるのは当然である。

第3の理由は，麻酔科学会・臨床麻酔学会におけ る議論においてさえも，「女性は男性の 2 倍努力し ても男性の半分にしか評価されない」というような, 歴史的に存在した(私はあえて過去形で書くことに する)女性医師に対する負のイメージが，繰り返し 述べられてきたからであろう。これは，今日の現実 と一致していないと私は考える。差別がないという 意味ではない。しかし，少なくとも私の世代および 私より若い世代は，自分が女性であることをむしろ 肯定的にとらえている。生まれ直しても女性に生ま れたいと考えている者が多い。そうであるのなら， 女性であるメリットを，もっと堂々と主張しょうで はないか.

こう考えてきたとき，私を含むパネリストたちは， 今回のパネルデイスカッションをぜひとも成功させ なければならないと思い至った。上記のような負の イメージを払拭するためにも，今回の企画は必要だ と確信したのである.

\section{IV 女性は男性より麻酔科医に適しているのか}

今回のパネルディスカッションを行うにあたつ て, 確認が必要な事項があった。女性医師は均一な 特性をもった集団ではない(すべての女性医師がす 


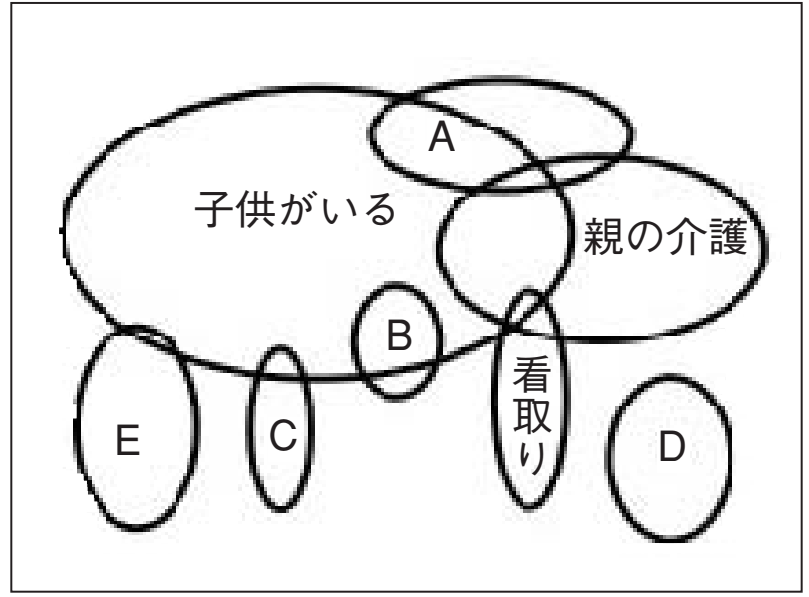

図4 女性は均一な特性をもった集団ではない

子供がいる, 肉親を看取った経験がある, 自分が婦 人科手術を受けたことがある (A), 帝王切開術を受け た経験がある(B)など, 女性のなかの, ある特性を有 する群について考察した。

べての男性医師より適している点など存在するはず がない)というきわめて当然の事柄である。私たち は，女性医師のなかに複数の群が存在する(図4)と 考え, 各群について論じることとした。群のなかに は，出産の経験がある ${ }^{2)}$, 育児経験がある ${ }^{3)}$, ある いは老親介護の経験のある女性 ${ }^{4)}$ というような比較 的大きな群もあるし，婦人科手術を受けた経験があ

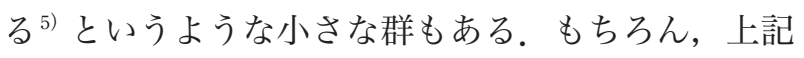
のどれにも属さず，男性以上に仕事に打ち込んでい る女性たちの群5)もある。そのそれぞれの群の女性 医師の麻酔科医としての適性について論じることに したのである.

そのなかで，私の選んだインフォームドコンセン ト (IC) というテーマは, 女性医師の比較的大きな群 が男性の平均よりも適性を有していると私は考える.

\section{$\mathrm{V} ＼mathrm{~ イ ン フ ォ ー ム ト ゙ コ ン セ ン ト(I C) ~}$}

最高裁の判例 (平成 13 年 11 月 27 日第三小法廷判 決)によれば，「医師は，患者の疾患の治療のために 手術を実施するに当たっては」緊急状態にあるなど の「特別の事情がない限り」, 診断, 手術の内容,
手術に付随する危険性，他に選択可能な治療法，予 後などについて，患者に説明する義務がある.

しかもその説明は，「患者が自らの身に行われよ うとする療法(術式)につき，その利害得失を理解し た上で，当該療法(術式)を受けるか否かについて熟 慮し，決断する」ために行われるものであるという。

すなわち，法的な説明義務に合致した麻酔の術前 説明と ICは，医学的に正しい知識を提供するだけ でなく，患者が麻酔を受ける「利害得失を理解」で きるものでなければならない。言いかえれば，いく ら正確な最新の知見であっても，それが相手の心に 意味のあるものとして届き，そのうえで患者自身が 「利害得失」を判断し, 療法(この場合は手術と麻酔) の可否を決められるのでなければ，ICにはなら ない。

患者やその家族の医学的知識や理解力はさまざま であるが，麻酔の合併症を医学用語で説明しても， たいていの場合は理解されない。 また，仮に，ICを 受ける患者またはその家族が医師であり，合併症に 列記されている病名をすべて知っていたとしても， その人物が，そういう合併症が生じたらどうなるか を具体的にイメージし，「利害得失」を考えられな いのであれば，ICとしては意味がない。

一方，合併症名などの医学用語が相手に伝わらな くても，麻酔とは「どうなること」であり，合併症 が起こるとしたら「どうなってしまうのか」という ことが，患者や家族にイメージできたのなら，それ はICとして成功しているのである。

したがって，ICを行うには，医学的知識だけでな く，患者や家族の心を理解できる力が必要である （誤解を避けるために繰り返すが，必要なのは，患 者の理解力ではなく, 私たち医療従事者の側の理解 力ないしは洞察力である).

この力は, 残念ながら医学教育では培われない. 医療の実践のなかでいろいろな患者に親身に接する ことにより養われるものであるが, 同時に, 病院の 外で,ささざまな人生経験をすることによっても, 
育てられていく.

\section{VI＼cjkstart相手の心への洞察力と女性}

女性は男性よりも，相手の心への洞察力を養いや すいと私は考える。それは, 女性が妊娠出産を経験 することがあり，しばしば育児や介護を担当すると いう，生物学的・社会的な特性と関係している。

もつとも，未婚の若い女性が男性よりも洞察力に 優れているとしたら, それは母性愛という本能の故 ではなく，その社会において女性が差別されている 故かもしれない。 女性が，男性を支え，内助の功を 発揮するものと考えている社会では, 周囲の大人た ちは，男児よりも女児に，思いやりややさしさを求 める。その結果，女性が男性より，思いやりに優れ ることになりがちである。

ただし，そのような社会においても，医師になる 女性はしばしば例外である。 小学生のときから学業 成績が優秀な, あるいは医師である父の後継者と家 族から期待された女児は，学校においても家庭にお いても，女性である故の差別を受けることはなく， 男性と同じ状態で医学部に入り医師となる.

その状態がそのまま続くのであれば，その女性が ICにおいて男性よりも優れることにはならない。し かし, その女性が妊娠, 出産, 老親の介護, あるい は看取りに直面するならば，状況は変わるかもしれ ない.

\section{VII＼cjkstart育児はすばらしい経験である}

このパネルディスカッションは，女性医師を均一 な特性の集団とは考元ない，いくつかの女性医師群 (図4)が有する特性について論じているにすぎない ことはすでに述べた。私のICの項では，まず，出 産，育児を経験した女性医師群について述べる。

妊娠出産は女性に課せられた苦行であるという宗 教的見知があるが，少なくとも育児は，仕事との両 立が辛くても，女性に(本来は男性にも)大きな喜び を与えるものではないだろうか. そのうえ，育児は，

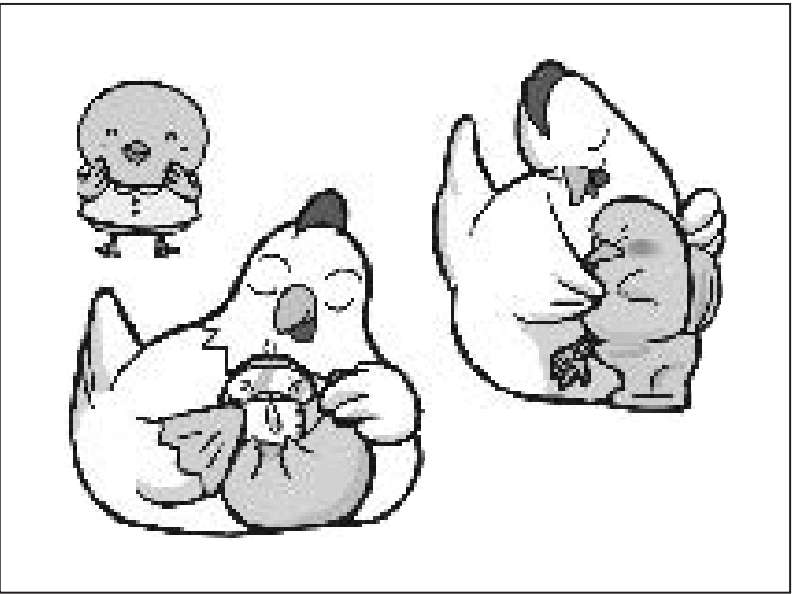

図5 子供たちは親と違った個性をもつ

子供たちは親と違った個性をもち, 違った人生を歩 む。だから，子供をもつことにより，子供の数だけ 異なった人生を身近に見ることができる。これは本 来，母親だけでなく父親にもあてはめることである.

人生経験の幅を大きく広げてくれる.

妊娠出産，育児で母親の立場を経験すること，お よび，子供の友人，その親たちとの交流などの経験 は，麻酔科医として決して無駄にはならない。少な くとも ICにおいては，大きく生きるはずである. しかし，母親となることの最大の醍醐味は，自分と 違う子供の人生を身近に見，ともに味わうことだと 私は考光る。

子供は他人よりは親に遺伝子が似ているが，親と 違った個性をもっている。病気や障害をもっている こともある. 図5は，市販のイラスト集を使って作 つた 1 羽の雌鵎と 3 羽のヒヨコのイラストである. お転婆でおしゃまなヒヨコ，アレルギー性結膜炎 （?）のヒヨコ，便秘もちのヒヨコという母鶏と違っ た個性をもったヒヨコたちに，母鶏は振り回されて いる。しかしそのなかで，母鶏は子供がいなければ できなかった「思い」を経験している。

さらに子供たちが成長し，それぞれ趣味をもち， 違う職業を選んでいけば，もっと多くのことを母親 は見ていくだろう。ただし，これは子供に親の理想 を押しつけることとは無縁である。供の自主的な 
判断を尊重しながら, その過程, 結果を身近に見て いくということである。そしてその経験が，ICにお いて, 患者や患者家族を理解する力として役立つは ずである。

一方，父親の方は，今の日本の社会では，意図的 に努力しないと母親と同じような子供との距離を保 つことができない。これを読んでおられる男性諸氏 には，育児を配偶者(子供の母親)任せにせず，積極 的に分担し, 子供の成人後も子供のよい相談相手で あり続けることをお勧めしたい。よい麻酔科医であ るためにも。

\section{VIII 介護そして看取り}

産科や小児対象の専門病院を除けば, 麻酔科医が 対象とする患者は高齢者が少なくないし, 死の可能 性を現実的なものとして感じている人たちも多い. こういう患者たちを理解するうえでより直接に役立 つのは，育児よりもむしろ，身内の病気，介護，あ るいは看取りなどの経験である ${ }^{4)}$.

一例提示という意味で，私自身のことを書かせて いただく。私の父親は 2 年前に呼吸不全のため 87 歳 で死去した。 父の死を契機に, 私の死生観や医療に 対する考え方は，大きくではないが確かに変わった。 第一に，医療は生きるためだけでなく，良い死に方 のためにもある，しかし同時に，俗に言う「トシに 不足のない」死期などありえない，というふたつの ことが身にしみてわかった，第二に，来世ないしは 魂の不滅を信じることは, 死者の家族の心を救うも のだということに気づいた。

それ以来，高齢者や根治性のない病気をもつ患者 とその家族との面談が，急に楽になった。ただ前だ けを見つめて手術と麻酔を受けるという道と, 静か で穏やかな死を受け入れるという選択肢の間の「利 害得失」の比較を患者と家族が「熟考」することを， 私自身が，理論としてばかりではなく，本心から受 け入れられるようになったからなのかもしれない。

私が，特に高齢の患者と，来世の存在を前提とし
たかのような会話をするのは以前からである。もち ろん，相手の反応を観察し，その宗教観や死生観を 推測しながらである。例えば，全身麻酔の手順の説 明のあと,

「先生，大丈夫ですやろか。そのまま目が覚め ないってことないやろか. まあ，それでもえ えんですけど.」

「そんな言うたらあかん。絶対とは言えないけ ど，たいていは大丈夫. (あの世の)お迎えはそ う簡単には来ません.」

「そうですか？」

そこから合併症の説明をして，時にはそのあとま た，下記のような会話になる。

「ご主人はいつごろ(あの世に)逝かはったんで したっけ.」

「そりやあんた，もう20年近うなります.」

「じゃあもうあの世でアンジョウ(無事なんとか 具合よく，というような意の方言. 広辞苑に よれば「味よく」の転という.)暮らしてはり ますよ．○○さんはご主人の分もこの世で楽 しんでいかなくちゃあ.(足腰が)痛い痛いじゃ つまらないから，ちょっとくらい危険があっ ても，気張って手術受けはりますか.」

「そうやねえ」

合併症についての説明をはさんで上記のような会 話があったとしても，相手の状況によっては，それ も ICの一つの形として許されると私は考える.

なお，身内の病気，介護，あるいは看取りへの関 与には，本来男女差はない。ただ残念ながら，今日 の日本では，女性の方が男性よりも介護に悩まされ ていることが多いように見える。男性も，自分の身 内の問題から目をそらしては，他人のICを行うこ とはできないと認識するべきである.

\section{IX 友人をもつこと, 近所付き合い, その他もろもろ}

育児，介護，看取りに限らず，医師として以外の 生活経験は, ICに役立つ。尒供や老親に限らず，家 
族，友人，知人を大切にすることが，IC に役立つの だと言うべきかもしれない.

以上述べたように，ICは女性の得意分野となりや

すい. しかしそれは, 男女の生物学的な差によるの

ではなく, 社会的な女性差別の結果, 女性が私生活 において男性よりも多くの仕事をかかえているから である。男性も，育児，肉親の病気，老化，看取り などに正面から取り組むことによって，ICにおける ハンディキャップはなくなる, すなわち男女差は解 消されていくであろう。

本稿には，麻酔科医師としての特性の男女差を， 固定したものとして主張する意図はない. 性差別の 解消は，女性が男性のように㗢くようになることだ
けではなく，男性も家族や家庭を大切にする余裕を 与えられることでなされなければならないと考える ものである.

\section{参考文献}

1）御村光子：「女性麻酔科医だからできること」によせ て.日臨麻会誌 $28 ： 247-251 ， 2008$

2）中江文：麻酔科医として体験した 3 度の帝王切開。日臨 麻会誌 $28 ： 259-265,2008$

3）間宮敬子：患者に優しい小児麻酔。日臨麻会誌 28 ： 273-280, 2008

4）合田由紀子：患者に優しい緩和医療。日臨麻会誌 $28 ：$ 281-288, 2008

5）小澤章子：過去2回の手術体験からの安全で快適な婦人 科手術の麻酔管理. 日臨麻会誌 $28 ： 266-272 ， 2008$

\title{
Informed Consent Process Can be Improved by the Anesthesiologist's Private Experiences as a Mother or as a Daughter
}

\author{
Kumi NAKAMURA \\ Department of Anesthesia, Kyoto City Hospital
}

\begin{abstract}
The informed consent process depends on the clinician understanding the feelings of patients and their families as well as their medical problems. The ability of anesthesiologists to obtain informed consent thus depends partly on their range of experiences both within and outside the hospital. At present, at least in Japan, female doctors are more likely than male doctors to care for their children or their older parents. These familial experiences provide the female doctor with the opportunity to understand the social and emotional aspects of their patients and their families, an understanding that is particularly useful in the informed consent process. Male doctors also can obtain this understanding by becoming more involved in the daily problems and activities of their own families. Sex discrimination should be resolved by giving women the same rights to work as men and also by allowing men more time to spend with their families.
\end{abstract}

Key Words : Informed consent, Female, Anesthesiologist

The Journal of Japan Society for Clinical Anesthesia Vol.28 No.2, 2008 